Santa Clara University

Scholar Commons

Psychology

College of Arts \& Sciences

$3-1997$

\title{
Personality expectations and perceptions of Roman Catholic clergy members
}

Thomas G. Plante

Santa Clara University, tplante@scu.edu

Marcus T. Boccaccini

Follow this and additional works at: http://scholarcommons.scu.edu/psych

Part of the Psychology Commons

\section{Recommended Citation}

Plante, T. G., \& Boccaccini, M. (1997). Personality expectations and perceptions of Roman Catholic clergy members. Pastoral Psychology, 45, 301-315.

The final publication is available at Springer via http://doi.org/10.1007/BF02282658

This Article is brought to you for free and open access by the College of Arts \& Sciences at Scholar Commons. It has been accepted for inclusion in Psychology by an authorized administrator of Scholar Commons. For more information, please contact rscroggin@scu.edu. 
Personality Expectations and Perceptions of Roman Catholic Clergy Members Thomas G. Plante 1,2,3 Marcus T. Boccaccini 1

This study examined the expectations of Roman Catholic priests' personality

characteristics. Personality measures (i.e., Symptom Check List-90-Revised, Weinberger Adjustment Inventory, Belief in Personal Control Scale, and several author-designed measures) were administered to 102 undergraduate students. The subjects' perceptions of Roman Catholic priests' personality traits were examined by having the subjects complete the Personality Adjective Checklist (PACL) describing a typical Roman Catholic priest. These scores were compared to PACL scores from 12 successful applicants to the priesthood. Findings suggest that subjects tend to view Roman Catholic priests stereotypically as authority figures and that Catholic subjects view priests more positively than do non-Catholic subjects. 
1 Psychology Department, Santa Clara University

2 Department of Psychiatry and Behavioral Sciences, Stanford University School of Medicine

3 Address correspondence to Thomas G. Plante, Psychology Department, Santa Clara University, Santa Clara, CA 95053. Electronic mail address:

TPLANTE@SCUACC.SCU.EDU. Telephone: 408-554-4471. 
A number of previous studies have investigated the personality of clergy

members including Catholic priests and Catholic seminary students (e.g., Banks,

Mooney,

Mucowski, \& Williams, 1984; Bier, 1948; Keddy, Erdberg, \& Sammon, 1990;

McCarthy,

1942; Plante, Manuel, \& Tandez, 1996, Weisgerber,1966), as well as Protestant

clergy

members (e.g., Ashbrook \& Powell, 1967; Ekhardt \& Goldsmith, 1984; Patrick,

1990, 1991). Much of the previous research has utilized the Minnesota Multiphasic

Personality

Inventory (MMPI); however, researchers have also used the Edwards Personal

Preference

Scales (EPPS) and the $16 \mathrm{PF}$ personality measure. Although both the range of

populations sampled and the measures utilized in these studies vary enormously, a 
review of the literature indicates that certain clergy personality trends have emerged.

As part of a comprehensive review of the literature, Nauss (1973)

investigated MMPI profiles of nine Protestant and two Catholic studies. This review

found a high degree of both similarity and uniformity among MMPI results

suggesting a pattern with elevations on the $\mathrm{K}, \mathrm{Hy}, \mathrm{Pd}, \mathrm{Mf}$, and Ma scales and low

scores on the Si scale. Nauss described the ministerial personality as being

characterized by "...extroversion, reflectiveness or intuitiveness, nurturance, and co-

operation, and environment ordering" (p. 89). Nauss further noted that Catholic

seminary students tended to be more introverted than Protestants.

In more recent research, Patrick (1991) administered the MMPI and the

Edwards Personal Preference Schedule (EPPS) to male and female pastoral

candidates in the United Church of Christ. Analogous to the findings of Nauss

(1973), Patrick concluded that MMPI scales K, Hy, Pd, and Ma were among the

five most deviated. Elevations on affiliation, interception, dominance, and 
nurturance were noted on the EPPS measure.

In an examination of 94 candidates for the Franciscan order, Banks et al.

(1984) found that these subjects had lower scores on the MMPI Si scale and

higher scores on the MMPI Sc scale, suggesting that subjects experienced

idiosyncratic thinking and a strong need for affiliation. Keddy et al. (1990) found

elevated $L$ scales on the MMPI suggesting priests often maintain defensive styles.

Dunn (1990) reviewed the professional literature concerning MMPI investigations

with Catholic priests and noted frequent elevations on the $\mathrm{Mf}, \mathrm{Pt}$, and $\mathrm{Sc}$ scales

and concluded that Catholic priests "...tend to be more perfectionistic, worrisome,

introversive, socially inept and in more extreme cases, perhaps more isolated and

withdrawn" (p. 133).

In a recent examination of 21 successful applicants to the priesthood, Plante

et al. (1996) found that Catholic clergy applicants tend to be generally well adjusted

with significantly low scores on MMPI-2 scales measuring anxiety (A and ANX), 
depression (DEP), anger (ANG), type A personality (TPA), and obsessions (OBS). However, Plante et al. (1996) found elevations on scales L and K, suggesting that Catholic clergy applicants maintain defensive styles. In addition to the MMPI-2, applicants also completed the 16 PF (fifth edition) personality measure in the Plante et al. (1996) study. The 16 PF results indicated that the subjects tend to be bright, imaginative, sensitive, emotionally stable, trusting, forthright, and self-assured.

Accompanied by the absence of elevations on MMPI-2 scales Pd, Ma, or Sc that had been found in previous research, the results allowed Plante et al. (1996) to conclude that relative to past research the study represented a more positive picture of Catholic clergy.

Several researchers have utilized clergy personality profiles to test specific hypotheses concerning the personality of clergy members. In an attempt to determine whether the choice of a religious occupation was associated with feminine interest patterns, Simono (1978) administered the MMPI to 41 undergraduate men 
who were entering a Protestant seminary, and found no such association. Francis and Pearson (1991) administered the Eysneck Personality Questionnaire (EPQ) to 40 male Anglican clergy in an attempt to examine their prediction that the personality profile of the clergy should follow the same pattern as the personality characteristics of religious laypersons. Contrary to predictions, clergy members displayed higher psychoticism and neuroticism scores than religious laypersons. Patrick (1990) administered the MMPI, the Millon Clinical Multiaxial Inventory, and the EPPS to 34 male and 30 female ministerial candidates in order to investigate the hypothesis that pathological narcissism is prevalent among the clergy. They found that when compared with norms from the EPPS scales, the ministerial candidates tended to be more dominant and less likely to blame themselves. Other research has examined how individual differences in personality manifest themselves within the clergy population. Francis and Raymond (1994) utilized EPQ results to show that "...Eysenck's major dimensions of personality 
(extroversion, neuroticism, and psychoticism) accounted for significant differences in... ministry performance and assessment" among Anglican clergy members ( $p$. 947). Specifically, individuals who scored high on both psychoticism and neuroticism showed many signs of dissatisfaction with clergy life and were most likely to entertain thoughts of seeking alternative forms of employment. They concluded that personality differences may predispose individual clergy to allow different groups to influence their view of ministry and their role prioritization. While many studies have examined the personality of clergy members, relatively few studies have attempted to examine expectations of the clergy personality. The research that has been conducted suggests that lay perceptions of clergy personality actively influence various aspects of parish dynamics. Avery and Gobbel (1980) investigated Lutheran Church members' expectations of sermon function and found that the laity's perceptions of the preacher's personality was pivotal in determining the judgments they made concerning each sermon. The 
authors theorized that positive personality perceptions increase open-mindedness regarding gospel interpretations while negative personality perceptions compelled the laity to quickly dismiss interpretations dissonant to their own.

In other related research, Perry and Hodge (1981) examined the relationship between individual Presbyterian pastors' perceptions of their own faith and the laity's expectations of their pastor's faith. They concluded that congregational growth was more heavily influenced by the laity's expectations than it was by the pastors' perceptions. Growth was determined to be greatest when the congregations perceived their pastor to be strict, conservative, and evangelistically oriented. Kennedy, Eckhardt, and Goldsmith (1984) reviewed the literature encompassing a wide variety of expectations concerning clergy members and theorized that church members' conflicting expectations for clergy personality presents the church with a major dilemma. In response to this dilemma of conflicting expectations, the authors voiced a need for research examining lay expectations of clergy personality, but no 
subsequent research has been published.

Examining the differences between the personality profiles of clergy members and the lay expectations of clergy personality has become increasingly relevant due to various crises within the church. Perhaps the most scandalous crisis plaguing the church today is that of sexual abuse (Plante, 1996). Unsympathetic media attention has attempted to paint a picture of clergy members as sexually deviant child molesters. Accounts of sexual abuse by clergy members have provided headline stories for such popular publications as Time (Ostling, 1991) and Rolling Stone (Burkett \& Gaboury, 1991). An article in America (Greely, 1990) claims that approximately 3,000 priests, or 1 in 15 nationwide, are probably guilty of sexual misconduct. Accompanied by the continual coverage of sexual abuse among the clergy by both daily newspapers and television newscasts, these articles indicate that the church is indeed facing an enormous crisis. 
while an additional $4 \%$ are ephebophiles (i.e., sexual attraction and behavior towards adolescents) (Sipe, 1990). Regardless, it has been estimated that between 1982 and 1992, the Roman Catholic Church spent 400 million dollars in legal fees associated with sexual abuse among clergy in the United States (Berry, 1992; Haywood, 1994), with estimates of about 1 billion dollars spent by the end of the 1990's (Chandler, 1990; de la Houssays, 1993; Quade, 1992).

Although the accounts of sexual abuse have garnered the most media attention, other church problems ranging from budget troubles (Goldman, 1991; Mallory, 1990) to priest suicides (Rossetti, 1994) have been brought into the public forum. The effect that these crises have had or will have on the church has yet to be determined.

No previous research has examined a multi-denominational group's personality expectations of any specific group of clergy. Expectations in all of the aforementioned studies were made in reference to a specific clergy member with 
whom the subjects from the varying denominations were personally acquainted.

The purpose of this study was to (a) examine how college students view members

of the Roman Catholic clergy, (b) determine if these views correspond with data

that has been collected from previous research on the personality profiles of

successful applicants to the Roman Catholic priesthood, (c) investigate the role of strength of religious faith and religious denomination within this view, and (d)

examine how faith has been affected by the crisis within the church.

The Symptom Check List-90-Revised (SCL-90R; Derogatis, 1977), Weinberger Adjustment Inventory (WAl; Weinberger, 1991), Belief in Personal

Control Scale (BPCS; Berrenberg, 1987), Personality Adjective Check List (PACL;

Strack, 1988) and a series of author-designed questions were administered to 102

undergraduates attending a liberal arts university during the fall of 1995.

\section{METHODS}

Subjects 
were utilized as research subjects for the student sample $(\underline{M}=19.25$ years, $\underline{S D}=$

2.24 years). All of the student subjects were enrolled in a General Psychology

course. The clergy sample included 12 successful applicants to the priesthood ( $\underline{M}$

$=29.00$ years, $\underline{S D}=8.16$ ).

Measures

Symptom Check List-90-Revised (SCL-90-R; Derogatis, 1977). The SCL-

90-R consists of 90 items scored on a 5 -point scale that reflect nine validated symptom dimensions. The anxiety, depression, and interpersonal sensitivity scales were used in the current study. For anxiety, Derogatis reports a coefficient alpha of .85 and test-retest reliability as .80 ; concurrent validity is reported as .74 . For depression, Derogatis reports a coefficient alpha of .90 and test-retest reliability as .82; concurrent validity is reported as .52 . For interpersonal sensitivity, Derogatis reports a coefficient alpha of .86 and a test-retest reliability of .83 ; concurrent 
validity is reported as .48 .

Weinberger Adjustment Inventory (WAl; Weinberger, 1991). The WAI is an

84-item personality questionnaire scored using a 5-point scale that assesses eleven

personality traits. The repressive defensiveness (WAI-RD), denial of distress (WAI-

DOD), and low self-esteem (WAI-LSE) subscales were utilized in this study.

Weinberger reports coefficients alphas as .79 for repressive defensiveness and .75

for denial of distress.

\section{Belief in Personal Control Scale (BPCS; Berrenberg, 1987). The BPCS}

is a 45 -item personality questionnaire designed to measure three dimensions of

personal control: general external control (F1), exaggerated control (F2), and God

control $(F 3)$. Higher scores relate more internal control $(F 1)$, a more exaggerated

belief in control (F2), and less belief in God as a mediator of control (F3).

Berrenberg reports coefficient alphas of .85 for the external control factor (F1), .88

for the exaggerated control factor (F2), and .97 for the God control factor (F3), 
and four-week test-retest correlations of .81 (F1), .85 (F2), and .93 (F3).

Personality Adjective Check List (PACL; Strack, 1988). The PACL is a

153-item adjective check list designed to measure nine personality traits. Raw

scores for each subscale are converted to standardized T-scores using sex and the

total number of items checked as scoring determinants. Strack reports coefficient

alphas ranging from .65 to .89 with a median value of .82 , and test-retest

correlations ranging from .63 to .89 at two months.

\section{Santa Clara Strength of Religious Faith Questionnaire (SCSORF; Plante \&}

Boccaccini , 1996). The SORF questionnaire is a 10-item measure designed by the author in order to measure strength of religious faith. Items on the SORF are scored on a 4-point scale and were designed to measure strength of religious faith regardless of denomination. Preliminary results have yielded a coefficient alpha of .95 .

Author-designed questions. Additional questions included a series of 10-point 
scale questions measuring strength of religious faith, perceived stress, and

perceived coping. One multiple choice question was included to determine whether

recent media accounts of priests sexually abusing children had diminished,

increased, or had no impact on the subject's faith.

\section{Procedure}

The subjects were informed of the purpose of the study and were assured of confidentiality. After signing a consent form and agreeing to participate, student subjects completed the series of questionnaires which included the SCL-90-R, WAI, PACL, and BPCS personality measures along with the five author-developed scales.

For the PACL measure, subjects were asked to complete the questionnaire describing a typical Roman Catholic priest.

\section{RESULTS}

The student sample included members of the Catholic $(\underline{n}=55,54 \%)$,

Protestant $(\underline{n}=21,21 \%)$, and Jewish $(\underline{n}=1,1 \%)$ faiths, while 18 subjects $(18 \%)$ 
indicated their adherence to no religious orientation and 7 subjects ( $7 \%)$ to various other religions (e.g., Buddhist, Muslim, and personal). The mean strength of faith scores were $6.06(\underline{S D}=2.73)$ on a 10 -point scale $[1=$ No faith, $10=$ Strong faith $]$ and $26.34(\underline{S D}=8.55)$ on the 10-item Strength of Religious Faith Questionnaire $[0=$ No faith, $40=$ Strong faith $]$. Subjects displayed a moderate amount of stress $(\underline{M}=6.10, \underline{S D}=2.11)$ and coping ability $(\underline{M}=6.70, \underline{S D}=1.87)$ using 10-point scales $[1=$ No stress, $10=$ Extreme stress; $1=$ Poor coping, $10=$ Excellent coping $]$. Only 8 subjects $(8 \%)$ indicated that the recent media accounts of Catholic priests sexually abusing children had diminished their faith. Means and standard deviations for selected variables are provided in Table 1.

[Insert Table 1 About Here]

Standardized T-scores were computed for each of the nine subscales on the PACL measure, and compared to PACL national norms $(\underline{M}=50, \underline{S D}=10)$ using $\underline{Z}$ scores. Significant $\underline{Z}$ scores were found for eight of the nine subscales and 
ranged from

-10.91 to 12.12 .

PACL scores from the entire sample were then compared to the PACL

scores of successful applicants to the priesthood. One-way analyses of variance (ANOVA's) were used to compare the PACL scores between the two groups for each of the nine subscales. The results indicate that students view Roman Catholic priests as less inhibited (PACL2: $\mathrm{F}(1,112)=16.32, \mathrm{p}<.000)$ and cooperative (PACL3: $\underline{F}(1,112)=4.80, \underline{p}<.05)$ than successful applicants to the priesthood see themselves; however, the students see Roman Catholic priests as more confident (PACL5: $\underline{F}(1,112)=14.59, \mathrm{p}<.000)$, forceful (PACL6: $\underline{F}(1,112)=$ 8.29, $\mathrm{p}<.01$ ), and respectful (PACL7: $\underline{\mathrm{F}}(1,112)=4.16, \underline{\mathrm{p}}<.04)$ than the successful applicants perceive themselves to be.

\section{[Insert Figure 1 About Here]}

A median-split procedure was used to divide the sample into high and low 
faith groups. Subjects with a score of 26 or above on the Strength of Religious Faith questionnaire were labeled as high faith whereas subjects who scored lower than 26 were labeled as low faith. Subjects were also separated into a Catholic and a non-Catholic group. A one-way analysis of variance (ANOVA) was computed for each score on the personality measures to examine differences as a result of strength of faith, and differences as a result of religious affiliation.

Results from the PACL measure indicate that high faith subjects see Roman Catholic priests as more sociable (PACL4: $\underline{F}(1,100)=7.87, p<.01)$ than do low faith subjects, who see Roman Catholic priests as more introversive (PACL1: $\underline{F}$ $(1,100)=4.56, \mathrm{p}<.05)$ and more respectful $($ PACL7: $\mathrm{F}(1,100)=4.85, \mathrm{p}<$ $.05)$. It was also found that Catholic subjects view Roman Catholic priests as more sociable $($ PACL4: $\underline{F}(1,100)=11.13, p<.001)$, forceful $($ PACL6: $\underline{F}(1,100)=$ 6.04, $\mathrm{p}<.05)$, respectful (PACL7: $\underline{\mathrm{F}}(1,100)=3.85, \underline{\mathrm{p}}<.05$ ), and sensitive (PACL8: $\underline{F}(1,100)=5.27, \underline{p}<.05)$, than do non-Catholic subjects, who view 
Roman Catholic priests as more introversive (PACL1: $\underline{F}(1,100)=11.04, p<$ $.001)$.

\section{[Insert Figures 2 and 3 About Here]}

The PACL scores for each of the four subgroups - high faith, low faith,

Catholic, and non-Catholic - were then each individually compared to the PACL

scores of successful applicants to the priesthood using independent sample t-tests.

The results illuminate some effects that were not apparent when the scores from the entire sample were compared to the scores from the successful applicants to the priesthood. The initial comparison found no significant difference between the scores for introversion (PACL1), but when the median split groups were separately examined it was found that both the low faith $(\underline{t}(60)=-2.49, p<.05)$ and nonCatholic $(\underline{t}(57)=-2.90, p<.01)$ groups view Roman Catholic priests as more introversive than successful applicants to the priesthood view themselves. Similarly, the results utilizing the entire sample indicated no significant difference in sociability 
scores (PACL4), but results from the median split groups indicate that both the low

faith $(\underline{t}(60)=2.01, p<.05)$ and non-Catholic $(\underline{t}(57)=2.08, p<.05)$ groups

see Roman Catholic priests as less sociable than the priests see themselves.

Results from the SCL-90-R indicate that high faith subjects are less

interpersonally sensitive than low faith subjects $(\underline{F}(1,100)=8.58, p<.01)$, and

WAI results suggest that high faith subjects have higher self-esteem than do low

faith subjects $(\underline{F}(1,100)=4.17, p<.05)$. On the BPCS measure, high faith

subjects scored higher on the exaggerated control dimension $(\underline{F}(1,100)=4.03, p$

$<.05)$ and lower on the God-mediated dimension $(\underline{F}(1,100)=99.08, p<.000)$,

with low scores on the God-mediated dimension indicating that the subject believes

that God can be enlisted in the achievement of outcomes. Results from the BPCS

also indicate that Catholic subjects scored lower on the God-mediated dimension (

$(1,100)=6.74, \mathrm{p}<.01)$ than did non-Catholic subjects.

DISCUSSION 
Findings from the PACL measure indicate that the sample experienced

priests as somewhat stereotypical authority figures. Subjects saw Roman Catholic priests as highly respectful when compared to both PACL norms and the scores of successful applicants to the priesthood. Although the sample rated Roman Catholic priests significantly low for both forcefulness and confidence, their scores were still significantly higher on both scales than those of the successful applicants to the priesthood.

Not surprisingly, Catholic subjects appear to harbor more positive perceptions of Roman Catholic clergy members than do non-Catholic subjects. Catholic subjects saw Roman Catholic priests as more respectful, more sensitive, more sociable, more forceful, and less introversive than non-Catholic subjects. Similarly, high faith subjects saw Roman Catholic priests more positively than low faith subjects, but not as positively as the Catholic sample. High faith subjects viewed Roman Catholic priests as more sociable and less introversive, but also less 
respectful than low faith subjects.

High faith subjects were found to have higher self-esteem, be less interpersonally sensitive, maintain a higher belief in extreme and unrealistic control, and were more likely to believe that God can be enlisted in the achievement of outcomes than were low faith subjects. It appears that high faith subjects may possibly maintain their high self-esteem through a combination of remaining less reactive to troubling interpersonal issues, enlisting the help of God in resolving these issues, and believing that they ultimately have the power to resolve any issue. These findings are consistent with previous research. Many researchers have found the same positive relation between religion and self-esteem (e.g., Frankel \& Helwitt, 1994; Jensen, Jensen, \& Wiederholder, 1993; Johnson \& Mullins, 1990; Sherkat \& Reed, 1992) indicating that high faith individuals consistently tend to maintain higher self-esteem. Other research has indicated that an external locus of control combined with religion can have positive effects on 
mental health. Tebbi, Mallon, Richards, and Bigler (1987) examined religiosity and locus of control of adolescent cancer patients and found that practicing religion provided subjects with support by offering security and understanding in the face of death.

The results from the personality expectation measures that were utilized in this study are difficult to compare to past research. No previous study has utilized the PACL measure when examining the personality profiles of any clergy member. The majority of studies conducted regarding clergy personality have used the MMPI which measures different constructs than the PACL. The PACL measure was desirable for this study because it is a brief adjective checklist and more appropriate than the MMPI for asking subjects to describe others.

Although methodological issues make direct comparisons to previous research difficult, some consistencies are apparent. Interestingly, the students "correctly" identified research-supported clergy personality characteristics, but rated 
the Roman Catholic priests higher on these characteristics that the successful applicants to the priesthood rated themselves. Concordant with the finding from the current investigation that students perceive Roman Catholic priests to be exceedingly forceful, Partick (1991) noted elevations on the dominance construct of the EPPS of pastoral candidates in the United Church of Christ, while Plante et al. (1996) found that 16 PF results indicated that Roman Catholic clergy members tend to be forthright. Similarly, the finding that students perceive Roman Catholic priests to be exceedingly confidant supports Plante et al.'s (1996) description of priest personality as being characterized by self-assuredness.

While previous research has described the ministerial personality as being characterized by both introversion (Dunn, 1990; Francis \& Pearson, 1991) and extroversion (Nauss, 1973), the current investigation found that successful applicants to the priesthood are no more introverted than national norms. However, the low-faith and non-Catholic groups perceived Roman Catholic priests to be highly 
introverted. Consistent with the Nauss (1973) review, the current study found that Catholic subjects perceived Roman Catholic priests to be more cooperative than did non-Catholic students.

Overall, the results of the current study suggest that considerable differences exist between the perceptions of clergy members' personality characteristics and actual clergy members' personality characteristics. High ratings on measures of respectfulness, forcefulness, and confidence suggest that laypersons appear to view clergy members stereotypically as authority figures. However, clergy members view themselves as more cooperative and more inhibited suggesting that they see themselves as more passive caregivers.

A variety of methodological issues suggest that the findings from this study must be viewed with caution. First, this study utilized a moderate sample of students from one university. Therefore, perceptions and conclusions could be associated with a myriad of factors (e.g., education, social class, and religious 
knowledge). Second, the considerable amount of analyses conducted given the moderate sample size increases the likelihood of Type I statistical errors. Third, this study examined only perceptions of Roman Catholic clergy members personality without examining the personality perceptions of other clergy members. Finally, it must remembered that when the students' PACL scores were compared to the clergy applicants' PACL scores, a set of self-perceptions were being compared to a set of perceptions about others. Future work should include larger samples, a diversity of religious groups and orders, and utilize a greater variety of subjects. 


\section{REFERENCES}

Ashbrook, J.B., \& Powell, R.K. (1967). Comparison of graduating and non-

graduating theological students on the Minnesota Multiphasic Personality

Inventory. Journal of Consulting and Clinical Psychology, 14, 171-174.

Avery, W.O., \& Gobbel, A.R. (1980). The word of God and the words of the

preacher. $\quad$ Review of Religious Research, 22, 41-53.

Banks, S., Mooney, W.T., Mucowski, R.J., \& Williams, R. (1984). Progress in the evaluation and pr

Berrenberger, J.L. (1987). The Belief in Personal Control Scale: A measure of

God- mediated and exaggerated control. Journal of Personality Assessment, 51,

194- 206.

Berry, J. (1992). Lead us not into temptation: Catholic priests and the sexual abuse

of children. New York, NY: Doubleday.

Bier, W.D. (1948). A comparative study of the seminary group and four other

groups on the MMPI. Studies in Psychology and Psychiatry from the Catholic 
University of America, 7, 107.

Burkett, E., \& Gaboury, D. (1993). The secret of St. Mary's. Rolling Stone, 669, 48-55.

Chandler, R. (1990, August 3). Sex abuse rocks the American clergy, LA Times, p.

A1.

de la Houssays, N. (1993). Liability of the church for the sexual misconduct of

church leaders. Loyola Law Review, 39, 313-338.

Derogatis, L.R. (1977). SCL-90-R Manual-I. Baltimore: Clinical Psychometric

research.

Dunn, P.J. (1990). Priesthood: A re-examination of the Roman Catholic theology of

the presbyterate. New York, NY: Alba House.

Ekhardt, B.N., \& Goldsmith, W.M. (1984). Personality factors of men and women pastoral candidate

Francis, L.J., \& Pearson, P.R. (1991). Personality characteristics of mid-career

male Anglican clergy. Social Behavior and Personality, 19, 81-84. 
Francis, L.J., \& Raymond, R. (1994). The influence of personality on clergy role

Frankel, B.G., \& Hewitt, W.E. (1994). Religion and well-being among Canadian prioritizatio

university

Goldman, A.L. (1991, July 11). Archdiocese will lay off 111 workers. The New York Times, p. B1.

Greely, A.M. (1993). How serious is the problem of sexual abuse by clergy?

America, $\quad \underline{168}, 6-11$.

Haywood, T.W. (1994). Cleric misconduct with minors: Minimization and self-

reported sexual functioning. Paper presented at the 13th annual conference of

the Association for the Treatment of Sexual Abusers, San Francisco, CA.

Jensen, L.C., Jensen, J., \& Wiederholder, T. (1993). Religiosity, denomination, and mental health among young men and women. Psychological Reports, 72 ,

$1157-1158$.

Johnson, M.A., \& Mullins, P. (1990). Moral communities: Religious and secular.

Journal of Community Psychology, 18, 153-166.

Keedy, P.J., Erdberg, P., \& Sammon, S.D. (1990). The psychological assessment 
Kennedy, K.A., Eckhardt, B.N., \& Goldsmith, M. (1984). Church members'

expectations of clergy personality. Journal of Psychology and Christianity, 3, 9-18.

Malloy, E.A. (1990). Church finances in crisis: How Catholic higher education can

help. America, 163, 104-106.

McCarthy, T.J. (1942). Personality traits of seminarians. Studies in Psychology and Psychiatry from th

Nauss, A. (1973) The ministerial personality: Myth or reality? Journal of Religion

and Health, 12, 77-96.

Ostling, R.W. (1991). Sins of the Fathers. Time, 138, 51-52.

Patrick, J. (1990). Assessment of narcissistic psychopathology in the clergy.

Pastoral Psychology, 38, 147-159.

Patrick, J. (1991). Personality characteristics of male and female pastoral

candidates. Journal of Psychology and Theology, 19, 186-196.

Perry, E.L., \& Hodge, D.R. (1981). Faith priorities of pastor and laity as a factor in 
the growth or decline of Presbyterian congregations. Review of Religious

Research, 22, 221-232.

Plante, T.G. (1996). Catholic priests who sexually abuse minors: Why do we hear

so much yet know so little? Pastoral Psychology, 44, 305-310.

Plante, T.G., \& Boccaccini, M. (1996). The Santa Clara Strength of Religious

Faith Questionnaire, under review.

Plante, T.G., Manuel, G., \& Tandez, J. (1996). Personality characteristics of successful applicants to the priesthood. Pastoral Psychology, 45, 29-40.

Quade, V. (1992). Unholy wars. Human Rights, 19, 18-21, 30.

Reilly, M.E. (1978). A case study of role conflict: Roman Catholic priests.

Rossetti, S.J. (1994). Priest suicides and the crisis of faith. America, 171, 8-13.

Sherkat, D.E., \& Reed, M.D. (1992). The effects of religion and social support on self- esteem and depression among the suddenly bereaved. Social Indicators

Research, 26, 259-275. 
Simono, R.B. (1978). Careers in the clergy: The myth of femininity. Educational

and Psychological Measurement, 38, 507-511.

Sipe, A.W.R. (1990). A secret world: Sexuality and the search for celibacy. New

York, NY: Brunner Mazel.

Strack, S. (1988). Manual for the Personality Adjective Check List (PACL).

Pasadena, CA: 21st Century Assessment.

Tebbi, C.K., Mallon, J.C., Richards, M.E., \& Bigler, L.R. (1987). Religiosity and

locus of control of adolescent cancer patients. Psychological Reports, 61, 683-

696.

Weinberger, D.A. (1991). Social-emotional adjustment in older children and adults: Psychometric prof

Weisgerber, C. (1966). The study of values in screening for a religious order.

Journal of Religion and Health, 5, 233-238. 